\title{
Trigeminal Sinir Dermatomu Yerleşimli Pediatrik Herpes Zoster
}

${ }^{1}$ Ayben Leblebici, ${ }^{2}$ Seher Tekeli, ${ }^{2}$ Merve İşeri Nepesov, ${ }^{3}$ Meltem Dinleyici, ${ }^{2}$ Ömer Kılıç, ${ }^{1}$ Ener Çağrı Dinleyici

${ }^{1}$ Eskișehir Osmangazi Üniversitesi Tip Fakültesi, Çocuk Sağlığı ve Hastalıkları Anabilim Dal,

Eskișehir, Türkiye

${ }^{2}$ Eskişehir Osmangazi Üniversitesi Tip Fakültesi, Çocuk Sağlığı ve Hastalıklar Anabilim Dalı,Çocuk Enfeksiyon Bilim Dalı, Eskişehir, Türkiye

${ }^{3}$ Eskişehir Osmangazi Üniversitesi Tip Fakültesi, Sosyal Pediatri Anabilim Dalı, Eskişehir, Türkiye

\author{
(1) \\ (1)
}

\section{Özet}

Herpes zoster diğer ismi ile zona, dorsal kök ganglionlarında latent kalan varisella zoster virüsünün reaktivasyonu sonucu ciltte veziküler lezyon olarak karşımıza çıkar. Birincil suçiçeği enfeksiyonundan veya aşı uygulamasından sonra herhangi bir zamanda görülebilir. Sağlıklı çocuklarda nadiren görülür ve çoğunlukla kendi kendini sınırlar. Altta yatan herhangi bir immünsupresyon öyküsü veya kronik hastalığı olmayan sekiz yaşında kız hasta, trigeminal sinir tutulumu ile seyreden zona tanısı ile oral asiklovir tedavisi alırken yeni döküntülerin ortaya çıkması, şiddetli ağrı şikayeti oluşması üzerine intravenöz asiklovir ile tedavi edildi. Ağr kontrolü için oral analjezikler ve topikal lidokain içerikli pomad uygulandı. Takiplerinde bakteriyel süperenfeksiyon gelişmesiyle trimetoprim-sulfametoksazol tedavisi verildi ve intravenöz asiklovir tedavisi 7 güne tamamlandı.

Anahtar Kelimeler: çocuk, herpes zoster, trigeminal sinir

\section{Abstract}

Correspondence:

Merve İŞERİ NEPESOY

Eskişehir Osmangazi Üniversitesi Tip

Fakültesi, Çocuk Sağlı̆̆ı 1 ve

Hastalıkları Anabilim Dalı, Çocuk

Enfeksiyon Bilim Dalı,

Eskişehir, Türkiye

e-mail: iserimerve@yahoo.com
Herpes zoster, also known as shingles, appears as a vesicular lesion on the skin as a result of the reactivation of varicella zoster virus, which remains latent in the dorsal root ganglia. Herpes zoster can develop at any time after the primary varicella infection or vaccination. It occurs rarely in healthy children and is mostly self-limiting. An eight-year-old female patient without any underlying immunosuppression history or chronic disease was treated with intravenous acyclovir due to the emergence of new rashes and severe pain while receiving oral acyclovir treatment with the diagnosis of herpes zoster with trigeminal nerve involvement Oral analgesics and topical lidocaine-containing ointment were applied for pain control. Trimethoprim-sulfamethoxazole treatment was given for bacterial superinfection and intravenous acyclovir treatment was applied for 7 days.

Keywords: child, herpes zoster, trigeminal nerve 


\section{Giriş}

Varisella zoster virüs (VZV), herpes virüs ailesinin alfa herpes grubundan olan çift sarmallı bir DNA virüsüdür. VZV'nin neden olduğu primer enfeksiyon suçiçeği olup virüs duyu sinirlerinin arka kök gangliyonlarında latent olarak kalır. Vahşi tip veya aşı tipi VZV ile ortaya çıkan primer bir enfeksiyon, herpes zoster için ön koşuldur (1). Latent virüsün konakta aktivasyonu herpes zoster ile sonuçlanır.

Herpes zoster gelişimi için risk faktörleri kadın cinsiyet, siyah 1rk, aile öyküsü ve komorbidite varlığıdır (2). Küçük çocuklarda herpes zoster daha çok servikal ve sakral dermatoma yerleşir (3). Yetişkinlerde lezyonlar alt torasik ve üst lomber dermatomlarda daha s1k görülür ve trigeminal siniri içerebilir (3). Herpes zoster tanıs1, belirgin klinik görünüm ve semptomatolojiye dayanarak klinik olarak konulur (4). Antiviral tedavinin amacı viral yükü azaltmak, kutanöz lezyonların iyileşmesini hızlandırmak, yeni lezyon oluşumunu önlemek, akut nörit ile ilişkili ağrıyı ve muhtemel komplikasyonları azaltmaktır (5). Bu çalışmada altta yatan herhangi bir hastalığı olmayan ve trigeminal sinir tutulumu ile seyreden sekiz yaşındaki zona olgusu sunulmuştur.

\section{Olgu Sunumu}

8 yaşında kız hasta 1 hafta önce sağ tragustan başlayıp ağzın sağ köşesine kadar yayılım gösteren döküntü şikayetiyle Çocuk Acil Birimine başvurdu. Döküntü dışında ek bir şikayeti yoktu. Hikayesinden bir hafta önce sağ tragus cildinde birkaç adet veziküler döküntü gelişmesi nedeniyle diş sağlık kuruluşuna başvurduğu ve azitromisin antibiyoterapisi başlandığı öğrenildi. Hastanın bilinen kronik hastalık öyküsü veya düzenli ilaç kullanımı yoktu. Suçiçeği aşısı uygulanmamış olup suçiçeği geçirme öyküsü mevcuttu. Döküntüleri herpes zoster olarak değerlendirilerek oral asiklovir $(80$ mg/kg/gün, 4 dozda) tedavisi başlandi. Oral asiklovir tedavisinin ikinci gününde döküntülerin gerilememesi, 4-5 adet benzer döküntünün sırtta da görülmesi ve şiddetli ağrı şikayetleriyle hasta tekrar başvurdu. Fizik muayenede; trigeminal sinirin mandibuler dalı tutulumu ile uyumlu olacak şekilde sağ diş kulak yolunda, sağ tragustan ağız köşesine kadar uzanan eritemli zeminde veziküler lezyonlar görüldü, şiddetli ağrısı mevcuttu (Resim 1). Sirtta herhangi bir dermatoma uymayan dağınık yerleşimli 5 adet veziküler döküntü görüldü. Fizik muayenesinde ek bulgu saptanmayan hastanın laboratuvar tetkiklerinde tam kan sayımı, kan biyokimyası, akut faz reaktanları normal bulundu.

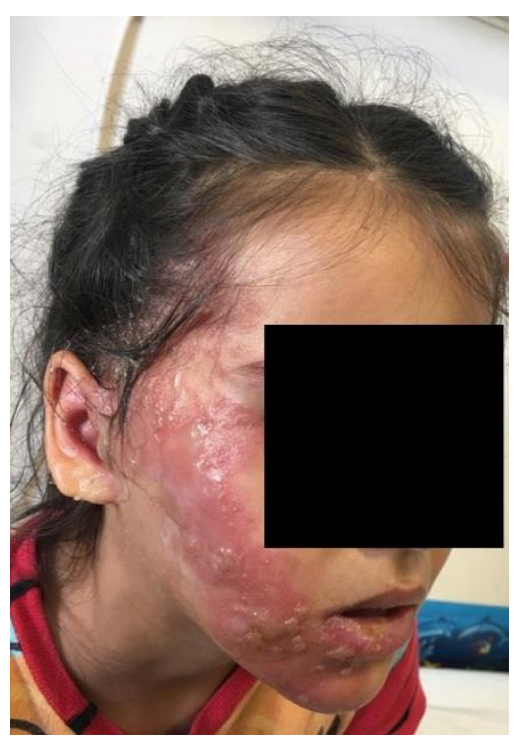

Resim 1. Trigeminal sinir dermatomu yerleşimli herpes zoster ile uyumlu veziküler döküntü 
Herpes zoster tanis1 konulan hastaya intravenöz asiklovir ( $30 \mathrm{mg} / \mathrm{kg} / \mathrm{gün}, 3 \mathrm{dozda})$ tedavisi başlandı. Lezyonların olduğu bölgede şiddetli ağrı olması üzerine Algoloji Bilim Dalının önerisiyle ibuprofen $(8 \mathrm{mg} / \mathrm{kg} / \mathrm{doz}$ günde $1 \mathrm{kez})$ ve parasetamol $(10 \mathrm{mg} / \mathrm{kg} / \mathrm{doz}$ günde $3 \mathrm{kez}$ ) tedavisi verildi, lezyonlara topikal lidokain içerikli pomad uygulandi; hastanın ağrı şikayeti geriledi. Dış kulak yolundaki veziküler lezyonlar nedeniyle Kulak Burun Boğaz Anabilim Dalının önerisiyle $\% 3$ burrow solüsyonu $3 \times 5$ damla 10 gün süreyle uygulandı. İşitme testinde her iki kulak duyma fonksiyonu normal olarak değerlendirildi. İntravenöz asiklovir tedavisinin ikinci gününde $38^{\circ} \mathrm{C}$ ateşi görülen hastanın fizik muayenesinde mevcut cilt lezyonları haricinde ateş odağı saptanmadı, laboratuvar tetkiklerinde akut faz reaktanlarında artış görülmedi, gönderilen kan kültüründe patojen bakteri üremesi görülmedi. Ciltte sekonder bakteriyel enfeksiyon düşünülerek trimetoprim-sulfametoksazol tedavisi başlandı. Döküntüleri ve ağrı șikayeti gerileyen hastanın intravenöz asiklovir tedavisi ve trimetoprim-sulfametoksazol tedavisi 7 güne tamamland. Hastanın taburculuk sonrası ikinci ay poliklinik kontrolünde fizik muayenede; sağ auriculadan malar bölge ve çeneye doğru uzanan dermatomal hat üzerinde yer yer eritemli, yer yer hiper veya hipopigmente maküler ve krutlu lezyonlar saptandı (Resim 2). Hastanın bir yıllık klinik izleminde iyilik halinin sürdüğü, ağrısının olmadığı belirlendi.

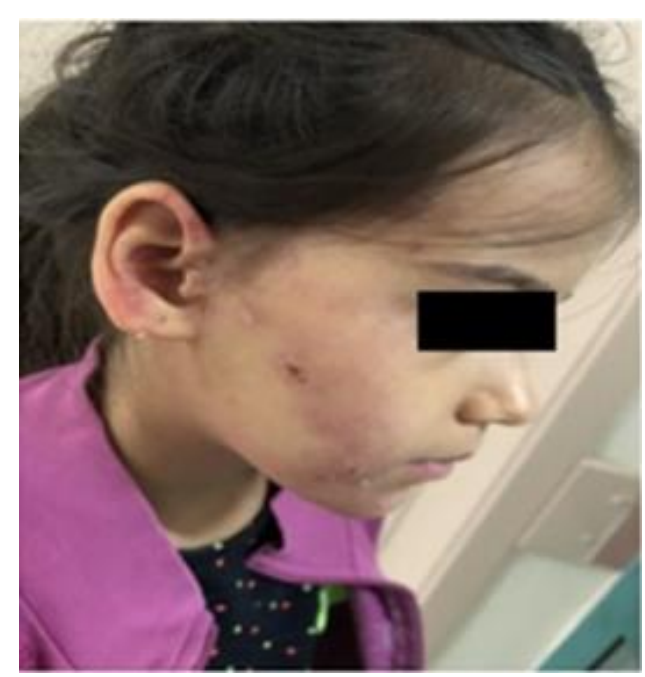

Resim 2. Trigeminal sinir dermatomu yerleşimli hiper ve hipopigmente maküler ve krutlu lezyonlar

\section{Tartışma}

Herpes zoster, virüse özgü hücresel bağışıklığın azalmasıyla latent VZV'nin yeniden aktive olmasından kaynaklanır. Genellikle ileri yaşlı veya immunsüpresif bireylerde görülsede tüm yaş gruplarında ve immünkompetan bireylerde de görülebilir (6). Yirmi altı ülkeden 130 çalışmanın dahil edildiği meta-analizde herpes zoster görülme sıklığ 1 yılda 3-5/1000 kişi arasında saptanmıştır (7). Yaş ve cinsiyete göre bakılan herpes zoster insidans1 ise genel populasyonda 3.2/1000 kişi iken bu oran 0-14 yaş arası çocuklarda 1.1/1000 kişidir (8). Genel olarak, yaşamın ilk y1lında enfekte olanlar hariç 10 yaş altında herpes zoster görülmesi nadirken, primer enfeksiyonu erken dönemde geçiren çocuklarda herpes zoster gelişme olasıllı̆̆ daha fazladır (9). İmmün sistemi baskılanmış bireyler, aynı yaştaki immünkompetan bireylerden belirgin daha yüksek risk taşır (10). Ayrica altta yatan astım, diyabet, böbrek yetmezliği, malignite gibi hastalık öyküsü olan çocuklarda zona gelişme riski daha fazladır $(11,12)$. Bizim olgumuz 8 yaşında kız 
hasta olup altta yatan herhangi bir hastalığ bulunmamaktaydi.

Herpes zoster, aşılama sonrası VZV aşı suşuna bağlı gelişebilmekte fakat vahşi tip su çiçeği sonrası gelişenden daha hafif seyretmektedir $(1,13)$. Varisella aşısı olan hem sağliklı hem de bağışıklığı baskılanmış çocuklarda herpes zoster insidansı, doğal varisella enfeksiyonu yaşayan çocuklardan daha azdır (1,13). Aşılı hastalarda herpes zostere bağlı döküntüler daha çok lumbosacral dermatomda ve az sayıda görülürken, 10 yaş altı vahşi tip varisellaya bağlı zona enfeksiyonu daha çok torasik dermatomda gözlenir (13). Ülkemizde suçiçeği aşısı Ocak 2012 tarihinden itibaren doğan 12. aydaki çocuklara tek doz olarak yapılmakta olup bizim olgumuzun suçiçeği aşısı bulunmamaktaydı (14).

Herpes zoster genellikle bir veya daha az yaygın olarak iki veya üç komşu dermatom alanında lokalize veziküler lezyon olarak başlar. Etkilenen bölgede parestezi, yanma veya kaşıntı olabilir (10). Lezyonlar genellikle orta hattı geçmez (4). Klinik çocuk yaş grubunda erişkine göre genellikle daha hafif seyirlidir. Veziküller büllöz lezyonlar oluşturmak için birleşebilirler (10). Veziküler ve büllöz lezyonlar 7-10 gün içerisinde püstüler veya bazen de hemorajik hale gelebilir ve sonuçta krutlanır $(10,15)$. Herpes zoster ilişkili iki tür ağrı tanımlanmış olup ilki duyusal nöronlarda VZV'ün reaktivasyonunun neden olduğu akut ağrıdır. İkincisi ise hastalığın akut fazı geçtikten sonra, genellikle iyileşmiş döküntü alanında gelişen postherpetik nevralji adı verilen ağrıdır. Çocuklarda postherpetik nevralji nadiren görünür (16). Bizim olgumuzda belirtiler sağ tragus cildinde birkaç adet veziküler döküntü ile başlamış olup 2 gün içerisinde sağ ağız köşesine kadar yayılmış, sırtta da orta hattı geçmeyecek şekilde veziküler döküntüler izlenmiştir. Ağrı ilk döküntü çıkmasının yedinci gününde şiddetlenmiştir.

Tanı için laboratuvar testleri genellikle gerekli değildir (4). Doğrudan floresan inceleme (FDA) tahlili kullanılarak cilt siyrıklarında veya veziküllerde spesifik viral antijenlerin gösterilmesi ile teşhis gerekirse doğrulanabilir. Lezyonun polimeraz zincir reaksiyonu (PCR) ile viral DNA analizi, vahşi tip ile aşı tipini ayırt etmek için kullanılabilir (4). Belirgin klinik görünümü ve tipik ağrısı olmas1 nedeniyle olgumuzda herhangi bir laboratuvar tanı testine gerek duyulmamıştır.

Sık görülen komplikasyonlar ikincil bakteriyel enfeksiyon, inflamasyon sonras1 depigmentasyon ve skar gelişimidir $(17,18)$. Herpes zoster oftalmik tutulumu şiddetli göz ağrıs1, konjonktivit, retina nekrozu, oftalmoparezi / pleji, sklerokeratit, ön üveit ve optik nörite yol açabilir (4). Herpes zoster akut döneminden sonra düzelmeyen bir ağr1 sürekliliğini temsil eden postherpetik nevralji, çocuklarda nadir görülür (15). Diğer nadir komplikasyonlar arasında Ramsay Hunt sendromu, Guillain-Barré sendromu, alt solunum yolu enfeksiyonu, aseptik menenjit, ensefalit, meningoensefalit, ventrikülit, miyelit, kraniyal ve periferik sinir parezi/pleji görülebilir $(4,10,17,19)$. Bizim olgumuza da asiklovir tedavisinin 2. gününde gelişen ateşinin sekonder bakteriyel enfeksiyon kaynaklı olabileceği düşünüldüğünden antibiyotik tedavisi 7 gün süreyle verildi. Oftalmik tutulum düşündüren herhangi bir bulgu saptanmad, izleminde postherpetik nevralji görülmedi.

İmmünkompetan çocuklarda herpes zoster çoğunlukla kendi kendini sınırlayan bir enfeksiyon olmasi nedeniyle antiviral tedavi tartışmalıdır, bununla birlikte asiklovir kullanımı cilt lezyonlarının daha hızlı iyileşmesinde ve akut ağrının giderilmesinde etkilidir (16). Immün sistemi baskılanmış yaygın hastalık riski taşıyan çocuklarda veya ciddi herpes zoster vakalarında intravenöz asiklovir tercih edilen tedavi yöntemidir $(4,16)$. İdeal ilaç uygulaması döküntü başlangıcının ilk 72 saatidir (15). Nevralji önlenmesinde antiviraller, topikal analjezikler ve nonsteroid anti inflamatuar ilaçlar kullanılabilir (4). Bizim olgumuzda, hastanın şikayetinin bir haftadır olması ve döküntünün bu süreçte giderek yaygınlaşması ayrıca akut şiddetli ağrının gelişmesi nedeniyle asiklovir tedavisi intravenöz olarak 7 gün boyunca verildi. Nevralji için oral ve lokal analjezik tedavi uygulandi. Tedavi sonrası birinci hafta kontrolünde tüm lezyonlarda belirgin gerileme gözlendi.

Sonuç olarak sağlıklı çocuklar da herpes zoster enfeksiyonu geçirebilmekte olup, klasik 
tutulum yerleri dışında atipik yerleşim görülebilmektedir. İmmunkompetan bireylerde hastalık genelde iyi seyirlidir ve komplikasyonsuz iyileşir. Hastamızda antiviral ve analjezik tedavi ile akut nörite bağl1 ağrı azalmış olup; kutanöz lezyonlarda iyileşme görülmüştür.

\section{KAYNAKLAR}

1. Chun C, Weinmann S, Riedlinger $\mathrm{K}$, et al. Laboratory characteristics of suspected herpes zoster in vaccinated children. Pediatr Infect Dis J. 2011;30:719-21.

2. Kawai K, Yawn BP. Risk Factors for Herpes Zoster: A Systematic Review and Metaanalysis. Mayo Clin Proc. 2017;92:1806-21.

3. Leung AK, Robson WL, Leong AG. Herpes zoster in childhood. $J$ Pediatr Health Care. 2006;20:300-3

4. Dayan RR, Peleg R. Herpes zoster - typical and atypical presentations. Postgrad Med. 2017;129:567-71.

5. Feder HM Jr, Hoss DM. Herpes zoster in otherwise healthy children. Pediatr Infect Dis $J$. 2004;23:451-7.

6. Hwang JH, Kim KH, Han SB, et al. A clinicoepidemiological multicenter study of herpes zoster in immunocompetent and immunocompromised hospitalized children. Clin Exp Vaccine Res. 2019;8:116-23.

7. Kawai K, Gebremeskel BG, Acosta CJ. Systematic review of incidence and complications of herpes zoster: towards a global perspective. BMJ Open. 2014;4:e004833.

8. Insinga RP, Itzler RF, Pellissier JM, et al. The incidence of herpes zoster in a United States administrative database. $J$ Gen Intern Med. 2005;20:748-53.

9. Stein M, Cohen R, Bromberg M, et al. Herpes zoster in a partially vaccinated pediatric population in central Israel. Pediatr Infect Dis J. 2012;31:906-9.

10. Staikov I, Neykov N, Marinovic B, et al Herpes zoster as a systemic disease. Clin Dermatol. 2014;32:424-9.

11. Hata A, Kuniyoshi M, Ohkusa Y. Risk of Herpes zoster in patients with underlying diseases: a retrospective hospital-based cohort study. Infection. 2011;39:537-44.

12. Kim BS, Mehra S, Yawn B, et al. Increased risk of herpes zoster in children with asthma: a population-based case-control study. $J$ Pediatr. 2013;163:816-21.

13. Civen R, Chaves SS, Jumaan A, et al. The incidence and clinical characteristics of herpes zoster among children and adolescents after implementation of varicella vaccination. Pediatr Infect Dis J. 2009;28:954-9.

14. T.C. Sağlık Bakanlığı, Türkiye Halk Sağlığı Kurumu. Suçiçeği aşısı uygulaması. 2013 (Erişim Tarihi:

11.3.2021). https://hsgm.saglik.gov.tr/dosya/mevzuat/genel ni telikli_yazilar/asi_db/sucicegi_asisi_uygulamasi_f edb8.pdf

15. Saguil A, Kane S, Mercado M, et al. Herpes Zoster and Postherpetic Neuralgia: Prevention and Management. Am Fam Physician. 2017;96:656-63.

16. Cherry JD, Harrison GJ, Kaplan SL, Steinbach WJ, Hotez PJ. (2019), Feigin and Cherry's Textbook of Pediatric Infectious Disease. 8th ed. Philadelphia: Elsevier.

17. El Hayderi L, Nikkels-Tassoudji N, Nikkels AF. Incidence of and Risk Factors for Cutaneous Scarring after Herpes Zoster. Am J Clin Dermatol. 2018;19:893-97.

18. Bader MS. Herpes zoster: diagnostic, therapeutic, and preventive approaches. Postgrad Med. 2013;125:78-91.

19. O'Connor KM, Paauw DS. Herpes zoster. Med Clin North Am. 2013;97:503-22. 